\title{
RESPONS VARIETAS DAN MUSIM TANAM TERHADAP PERTUMBUHAN, HASIL DAN KUALITAS JAMUR TIRAM
}

\author{
Response of Variety and Planting Season on Growth, Yield \\ and Quality of Oyster Mushroom \\ Deden Fatchullah $^{1}{ }^{*}$, Ramdani Abdul Rahman ${ }^{1}$ dan Endeh Masnenah ${ }^{2}$ \\ ${ }^{1)}$ Balai Penelitian Tanaman Sayuran \\ Jln. Tangkuban Perahu No. 517 Lembang, Bandung Barat 40791 \\ ${ }^{2)}$ Kopertis Wilayah IV DPK Fakultas Pertanian Universitas Bandung Raya \\ *Email: fatchullah1960@gmail.com
}

\begin{abstract}
ABSTRAK
Jamur tiram putih merupakan komoditas sayuran prospektif, petensial dan bernilai ekonomi tinggi. Penelitian bertujuan untuk mendapatkan varietas jamur tiram putih yang dapat beradaptasi, berdaya hasil dan berkualitas tinggi dibudidayakan di Bogor - Jawa Barat pada musim kemarau dan musim hujan. Rancangan percobaan menggunakan Rancangan Acak Kelompok dengan 4 ulangan. Perlakuan terdiri atas 6 varietas jamur tiram putih, yaitu varietas No. 1, 30, 37, 38, 46 (asal dari koleksi Balai Penelitian Tanaman Sayuran), dan varietas No. 85 (asal dari petani Bogor, sebagai varietas kontrol) yang dibudidayakan pada musim kemarau dan musim hujan. Hasil penelitian menunjukkan bahwa varietas dan musim berpengaruh terhadap pertumbuhan jamur. Varietas tidak berpengaruh terhadap produksi jamur berkisar 55-91 ton per $1000 \mathrm{~m}^{2}$ luas kumbung, sedangkan musim tanam berpengaruh. Produksi jamur tiram di musim kemarau mencapai 91,3 ton sedangkan di musim hujan mencapai 61,7 ton. Varietas berpengaruh terhadap qualitas jamur tiram sedangkan musim tidak berpengaruh nyata yaitu diperoleh nilai ranking rasa $<3$, ketahanan simpan sampai 2 hari, dan kadar air $>90 \%$.
\end{abstract}

Kata kunci: Musim tanam, Pleurotus ostreatus, produksi, jamur tiram, varietas

\begin{abstract}
Oyster mushroom was a prospective vegetable commodity and has high economical value. The aim of this research was to find out oyster mushroom varieties that could be adapted in Bogor - West Java, and produced high yield and quality when cultivated both in the dry and rainy seasons. A Randomized Block Design with 4 replications were set up in mushroom houses during the dry and the rainy seasons. Treatments comprised of 6 varieties of oyster mushrooms, viz: varieties No. 1; 30; 37; 38; 46 (origin from IVEGRI's collection) and No. 85 (origin from Bogor as control variety). The result showed that varieties and planting seasons has significantly effect on growth of oyster mushroom. However varieties has no significantly effect on yield of mushroom which was in average $55-91$ ton/1000 $\mathrm{m}^{2}$ of mushrooms house area. Fresh yield of mushroom planted in dry season (91.3 ton) was significantly higher than those in wet season (61.7 ton). Varieties has significantly effect of mushroom quality, meanwhile seasons gave a same good quality with delicious/ ranking <3, storage resistance up to 2 days at room temperature and water content $>90 \%$.
\end{abstract}

Keywords: Planting season, Pleurotus ostreatus, growth, yield, quality

\section{PENDAHULUAN}

Banyak jenis jamur yang dibudidayakan sebagai bahan makanan yang dapat meningkatkan kesehatan (Valverde et al., 2015). Cina diperkirakan memiliki 15002000 spesies jamur yang dapat dimakan dimana 981 spesies telah teridentifikasi, 92 spesies telah terdomestikasi, dan 60 spesies telah dibudidayakan secara komersial 
(Chang, 2008). Jamur tiram putih (Pleurous ostreatus) merupakan spesies yang dikomersialkan serta dominan dibudidayakan oleh petani Indonesia sejak tahun 1960-an. Jenis jamur edible lainnya yang umumnya dikomersialkan oleh petani Indonesia sampai saat ini adalah jamur merang, jamur kuping, jamur shitake, dan jamur kancing (Pasaribu et al., 2002).

Jamur edible umumnya, termasuk jamur tiram putih, merupakan organisme tidak berkhlorofil. Karena itu jamur edible tidak dapat melakukan fotosintesis serta tidak dapat memanfaatkan secara langsung energi matahari untuk memproduksi senyawa organik untuk pertumbuhan dan perkembangannya. Jamur tiram termasuk kedalam grup Bacidiomycetes yang memproduksi spora atau basidia dan merupakan organisme saprofit, yaitu mampu mendegradasi bahan organik asal dari bahan mati/limbah pertanian, seperti daun kering, jerami, kotoran hewan, bekatul/dedak, bijibijian, dan lain-lain untuk sumber makanannya. Jamur edible memiliki enzim yang diproduksi oleh hifa/miselium. Karena itu jamur edible mampu mendegradasi bahan kimia berantai panjang dan bermolekul besar seperti lignin, selulosehemi-selulose, karbohidrat, protein, polutan organik (PAH, PCB, Dioksin) dan lain-lain menjadi bahan organik bertantai pendek/ sederhana sehingga mudah diserap dan digunaka oleh miselium jamur untuk pertumbuhannya (Oei, 2003). Karena itu formula media bibit dan media produksi untuk menumbuhkan miselium jamur tiram disusun dari berbagai bahan limbah pertanian. Namun, setiap varietas/strain berbeda akan memberikan respons berbeda dalam pertumbuhan, perkembangan, dan hasil produksi jamur tiram. Faktor potensi genetik suatu spesies/barietas jamur tiram berinteraksi dengan nilai faktor lingkungan cuaca serta $\mathrm{pH}$ media dalam pertumbuhan miselium, perkembangan serta hasil jamur pada akhirnya. Karena itu berbagai faktor itu perlu mendapat perhatian serius, bila hasil produksi jamur tiram ingin tinggi.
Benih $\mathrm{F}_{0}$ jamur tiram putih yang dibudidayakan petani Indonesia berasal dari negara luar (introduksi). Namun, tidak semua varietas yang diintroduksi berkualitas dan berdaya hasil tinggidan sesuai/ beradaptasi baik pada semua lokasi di Indonesia. Karena itu suatu varietas asal introduksi harus terlebih dahulu mengalami proses isolasi, pemurnian, seleksi uji daya hasil dan kualitas, serta uji adaptasi multilokasi pada kondisi setempat untuk menentukan apakah varietas introduksi tersebut dapat beradaptasi luas sepanjang tahun dan berproduksi serta kualitas tinggi bila dibudidayakan di tempat tersebut dengan mennggunakan teknologi setempat/petani. Untuk membangkitkan semangat usahatani jamur tiram putih di Indonesia, Balai Penelitian Tanaman Sayuran (BALITSA) telah melakukan serangkaian kegiatan penelitian untuk menghasilkan serta menyediakan varietas unggul benih jamur tiram putih yang mudah diakses pengguna (Djuariah dan Sumiati, 2005a, 2005b, 2006, 2007, 2008a dan 2008b).

Sentra produksi jamur tiram putih di Pulau Jawa, yaitu lokasi yang memiliki nilai suhu udara $10-21^{\circ} \mathrm{C}$, RH udara $85-95 \%$. Syarat tumbuh lainnya yaitu konsentrasi $\mathrm{CO}_{2}<1000$ ppm, dan intensitas cahaya 1000 - 1500 lux (Stamets, 2000). Miselium jamur tiram putih tetap viable pada suhu $\left(\mathrm{T}_{\mathrm{mg}}\right)$ antara 5-35 ${ }^{\circ} \mathrm{C}$. Suhu untuk terjadi pembentukan bakal tubuh buah / fruiting antara $5-25^{\circ} \mathrm{C}$ (Oei, 2003).

Hasil survei se-Jawa dan Bali mengungkapkan bahwa rata rata hasil jamur di tingkat petani rendah, yaitu $<200 \mathrm{~g}$ per $\mathrm{kg}$ substrat (Sumiati dan Djuariah, 2009). Hasil yang rendah ini penyebabnya antara lain mungkin karena petani tidak mengevaluasi terlebih dahulu varietas yang akan digunakan untuk usaha taninya. Meskipun suatu varietas introduksi yang di klaim berkualitas dan berdaya hasil tinggi, ketika dibudidayakan di lokasinya tidak berproduksi maksimal. Kemungkinan lain, petani tidak mengikuti sepenuhnya SPO 
(Standar Prosedur Operasional) teknologi budidaya, antara lain lingkungan yang tidak higienis yang mengakibatkan terjadinya kontaminasi yang tinggi, serangan hama, dan lainnya, yang berakibat kepada penurunan hasil produksi jamur tiram putih.

Penelitian bertujuan untuk mendapatkan varietas jamur tiram putih terseleksi yang berdaya hasil dan berkualitas tinggi serta beradaptasi baik sepanjang tahun di daerah Bogor - Jawa Barat. Satu atau lebih veriatas jamur tiram putih yang diuji pada dua musim berbeda di Bogor, berkulitas dan berdaya hasil tinggi.

\section{METODE PENELITIAN}

Penelitian dilakukan di kumbung milik petani desa Tangkil, Kecamatan Caringin, Kabupaten Bogor pada ketinggian tempat $800 \mathrm{mdpl}$. Rancangan percobaan menggunakan Rancangan Acak Kelompok (RAK) dengan 4 ulangan. Jamur tiram dibudidayakan pada musim kemarau dan musim hujan. Perlakuan terdiri dari 6 varietas jamur tiram putih, yaitu 5 varietas (No. 1, No. 30, No. 37, No. 38, dan No. 46) asal koleksi BALITSA, dan satu veritas No. 85 asal dari koleksi petani Bogor yang biasa digunakan untuk usaha taninya sebagai kontol. Peubah yang diamati dan dianalisis terdiri atas:

1. Pertumbuhan vegetatif miselium benih kultur murni $\left(\mathrm{F}_{0}\right)$ pada media PDA (perbanyakan benih $\mathrm{F}_{0}$ ),

2. Pertumbuhan vegetatif miselium benih $\mathrm{F}_{0}$ pada media biji-bijian (sebagai benih $\mathrm{F}_{1} /$ benih induk/benih sebar),

3. Perumbuhan vegetatif miselium benih $\mathrm{F}_{1}$ pada media produksi/ substrat,

4. Hasil dan komponen hasil jamur tiram putih,

5. Kualitas jamur tiram putih (kadar air, ketahanan simpan pada suhu kamar di Temanggung, dan rasa jamur dengan tes organoleptik).

Tes rasa jamur menurut metodologi pasca panen, yaitu menggunakan metode ranking dengan nilai rasa jamur ditentukan berkisar antara 1 sampai 4, yaitu berturut turut: (1) sangat enak, (2) enak, (3) kurang enak, dan (4) tidak enak. Metode ini digunakan karena sampai saat ini belum diketahui zat apa yang menyebabkan rasa enak atau tidak enak pada jamur tiram putih atau tidak dapat dilakukan uji laboratorium yang lebih obyektif dibandingkan dengan tes rasa yang bersifat subyektif karena menggunakan lidah responden yang mencicipi jamur berbeda-beda. Namun tes ini masih digunakan dalam ilmu pasca panen hasil olahan makanan (Pantastico, 1989).

Cara tes kerja rasa adalah sebagai berikut :

1. Tudung jamur tiram putih dicuci dan kemudian direbus dengan air bersih mendidih selama 2-3 menit.

2. Jamur tiram yang telah direbus ditiriskan, didinginkan, dan ditata diatas piring porselin untuk dicicipi responeden.

3. Mengundang sedikitnya 10 orang responden yang mewakili berbagai kelompok jender, pendidikan, dan status sosial untuk mencicipi rasa jamur tiram putih rebus.

4. Setiap kali responden selesai mencicipi satu varietas jamur, responden diharuskan meminum air putih matang dingin/hangat terlebih dahulu sebelum melanjutkan mencicipi varietas jamur yang berikutnya sampai ke enam varietas selesai dicicipi.

5. Setiap responden memberikan angka penilaian untuk ke enam varietas jamur tiram putih dengan nilai ranking 1-4.

6. Cara menghitung nilai ranking kumulatif tes rasa adalah sebagai berikut: Misalnya:

a. Dua responeden memberi nilai 1 (sangat enak). Jumlah nilai diperoleh: 2 x $1=2$;

b. Lima responden memberi nilai 2 (enak). Jumlah nilai diperoleh: 5 × $2=10$;

c. Dua responeden memberi nilai 3 (kurang enak). Jumlah nilai diperoleh: 2 × $3=6$;

d. Satu responden memberi nilai 4 (tidak enak). Jumlah nilai diperoleh: 1 x $4=4$. Total nilai kumulatif rata-rata dari 10 responden $=22 / 10=2,2$. 
Kesimpulan: jamur tiram yang di tes, enak rasanya (nilai ranking 2,2 $=$ enak).

Jumlah populasi baglog substrat 100 per varietas per ulangan. Ditambah dengan cadangan $20 \%$ dari total populasi baglog substrat yang diuji untuk antisipasi terjadi kontaminasi dan serangan hama (maksimal 10\%) selama pertumbuhan dan perkembangan jamur. Jumlah sampel untuk pengamatan/pengukuran pertumbuhan vegetatif dan generatif (destruktif) adalah $20 \%$ per varietas per ulangan. Untuk pengamatan produksi total jamur tiram putih dari mulai panen ke 1 sampai terakhir panen, diakumulasikan dari total jumlah populasi baglog substrat per varietas per ulangan.

Baglog substrat yang telah $100 \%$ ditumbuhi miselium benih sebar, dipindah dari ruang inkubasi ke dalam ruang budidaya/ ruang penumbuhan/ kumbung jamur. Baglog substrat diletakkan pada rak bambu yang terdiri atas 5 ruang sub rak secara berdiri. Data hasil penelitian dianalisis sidik ragam gabungan pada $\mathrm{P} 0,05$ dan dilanjutkan dengan uji jarak berganda duncan pada $\mathrm{P} 0.05$ bila terjadi perbedaan nyata diantara perlakuan varietas dan waktu budidaya.

\section{HASIL DAN PEMBAHASAN}

\section{Waktu Awal Tumbuh pada Media PDA}

Pertumbuhan dan perkembangan jamur tiram putih normal, sehat, segar, warna tudung jamur putih. Kontaminasi substrat $2,5 \%$, tidak ada serangan hama di kumbung. Data pada Tabel 1, secara independen waktu awal tumbuh miselium benih $\mathrm{F}_{0}$ varietas No. 1, 30, 37, dan 85 (lokal bogor) pada media kultur murni PDA, nyata lebih cepat $(2,13$ sampai 2,63 hsi (hari setelah inokulasi miselium benih pada media PDA) dibandingkan dengan varietas No. 38 dan 46 (3,13 sampai 3,25 hsi). Hal ini kemungkinan karena setiap varietas berbeda memberikan respons berbeda pula terhadap waktu awal tumbuh miselium benih $\mathrm{F}_{0}$ pada media PDA.
Tabel 1. Pengaruh varietas dan musim terhadap waktu awal tumbuh miselium benih $\mathrm{F}_{0}$ pada media kultur murni PDA

\begin{tabular}{|c|c|c|}
\hline Perlakuan & Waktu awa & tumbuh \\
\hline Varietas & $\ldots$. hsi ...... & \\
\hline No. 1 & 2,13 & $\mathrm{c}$ \\
\hline No. 30 & 2,50 & $\mathrm{c}$ \\
\hline No. 37 & 2,50 & $\mathrm{c}$ \\
\hline No. 38 & 3,25 & $\mathrm{a}$ \\
\hline No. 46 & 3,13 & $a b$ \\
\hline No. 85 (kontrol) & 2,63 & $\mathrm{bc}$ \\
\hline Musim & & \\
\hline Kemarau & 2,42 & $\mathrm{~b}$ \\
\hline Hujan & 2,96 & $\mathrm{a}$ \\
\hline Hasil analisis sidik & \multirow{2}{*}{\multicolumn{2}{|c|}{$\begin{array}{l}\mathrm{V}^{\mathrm{n}} ; \mathbf{M}^{\mathrm{n}} ; \mathrm{VxM}^{\mathrm{tn}} \\
\mathrm{KK}=13,68 \%\end{array}$}} \\
\hline ragam gabungan & & \\
\hline
\end{tabular}

Secara independen, waktu awal tumbuh miselium benih $\mathrm{F}_{0}$ pada media PDA ke enam varietas jamur tiram putih yang dibudidayakan pada musim kemarau nyata lebih cepat (2,52 hsi) dibandingkan dengan musim hujan (2,96 hsi). Kemungkinan berbagai nilai faktor cuaca di musim kemarau optimal untuk mendukung pertumbuhan miselium benih $\mathrm{F}_{0}$ yang lebih cepat sehingga waktu yang dibutuhkan untuk awal tumbuh miselium benih $\mathrm{F}_{0}$ pada media PDA menjadi lebih singkat dibanding pada budidaya musim hujan.

\section{Lama Waktu pertumbuhan pada Media PDA}

Terjadi pengaruh interaksi antara varietas dengan waktu budidaya terhadap waktu akhir tumbuh serta lama waktu pertumbuhan miselium benih $\mathrm{F}_{0}$ pada media PDA (Tabel 2). Waktu akhir tumbuh miselium benih $\mathrm{F}_{0}$ varietas No 1 pada media PDA yang nyata tercepat berasal dari budidaya musim hujan (5 hsi) dibandingkan dengan pada budidaya musim kemarau. 
Tabel 2. Interaksi antara varietas dengan musim terhadap waktu akhir tumbuh dan lama waktu pertumbuhan miselium benih $\mathrm{F}_{0}$ pada media PDA

\begin{tabular}{|c|c|c|c|c|}
\hline \multirow{3}{*}{$\begin{array}{l}\text { Perlakuan } \\
\text { Varietas }\end{array}$} & \multicolumn{2}{|c|}{$\begin{array}{l}\text { Waktu akhir tumbuh miselium } \\
\text { benih } \mathrm{F}_{0} \text { pada media PDA }\end{array}$} & \multicolumn{2}{|c|}{$\begin{array}{c}\text { Lama waktu pertumbuhan miselium benih } \\
\mathrm{F}_{0} \text { memenuhi media PDA }\end{array}$} \\
\hline & \multicolumn{2}{|c|}{ Musim } & \multicolumn{2}{|c|}{ Musim } \\
\hline & Kemarau (hsi) & Hujan (hsi) & Kemarau (hsi) & Hujan (hsi) \\
\hline No. 1 & $\begin{array}{c}6,25 \text { bc } \\
\text { A }\end{array}$ & $\begin{array}{c}5,00 \mathrm{~b} \\
\mathrm{~B}\end{array}$ & $\begin{array}{c}4,25 \mathrm{ab} \\
\mathrm{A}\end{array}$ & $\begin{array}{c}2,75 \mathrm{~b} \\
\mathrm{~B}\end{array}$ \\
\hline No. 30 & $\begin{array}{c}6,50 \mathrm{~b} \\
\mathrm{~A}\end{array}$ & $\begin{array}{l}5,50 \mathrm{ab} \\
\mathrm{A}\end{array}$ & $\begin{array}{c}4,50 \mathrm{ab} \\
\mathrm{A}\end{array}$ & $\begin{array}{c}2,50 \mathrm{~b} \\
\mathrm{~B}\end{array}$ \\
\hline No. 37 & $\begin{array}{rl}5,25 & \mathrm{c} \\
\mathrm{A} & \end{array}$ & $\begin{array}{l}5,50 \mathrm{ab} \\
\mathrm{A}\end{array}$ & $\begin{array}{c}3,00 \mathrm{c} \\
\mathrm{A}\end{array}$ & $\begin{array}{c}2,75 \mathrm{~b} \\
\mathrm{~A}\end{array}$ \\
\hline No. 38 & $\begin{array}{rl}6,75 & \mathrm{ab} \\
\mathrm{A}\end{array}$ & $\begin{array}{r}6,25 \\
\mathrm{~A}\end{array}$ & $\begin{array}{rl}3,75 & b c \\
A\end{array}$ & $\begin{array}{c}2,75 \mathrm{~b} \\
\mathrm{~A}\end{array}$ \\
\hline No. 46 & $\begin{array}{r}7,75 \text { a } \\
\text { A }\end{array}$ & $\begin{array}{c}5,75 \mathrm{ab} \\
\mathrm{B}\end{array}$ & $\begin{array}{r}4,75 \text { a } \\
\mathrm{A}\end{array}$ & $\begin{array}{c}2,50 \mathrm{~b} \\
\mathrm{~B}\end{array}$ \\
\hline No. 85 (kontrol) & $\begin{array}{rl}5,25 & \mathrm{c} \\
\mathrm{A} & \end{array}$ & $\begin{array}{c}6,00 \text { ab } \\
\text { A }\end{array}$ & $\begin{array}{c}3,25 \mathrm{c} \\
\mathrm{A}\end{array}$ & $\begin{array}{c}3,00 \\
\mathrm{~A}\end{array}$ \\
\hline $\begin{array}{l}\text { Hasil Analisis } \\
\text { Sidik Ragam }\end{array}$ & \multicolumn{2}{|c|}{$\mathrm{V}^{\mathrm{n}} ; \mathrm{M}^{\mathrm{n}} ; \mathrm{VM}^{\mathrm{n}}$} & $\mathrm{V}^{\mathrm{n}} ; \mathrm{M}^{\mathrm{n}} ; \mathrm{VM}^{\mathrm{n}}$ & \\
\hline
\end{tabular}

Keterangan: Pada kolom yang diikuti huruf kecil yang sama tidak berbeda pada uji Duncan 5\%

Sedangkan varietas No. 46 memberikan waktu akhir tumbuh miselium benih $\mathrm{F}_{0}$ pada media PDA yang nyata paling lambat berasal dari budidaya pada musim kemarau $(7,75$ hsi) dibandingkan dengan pada budidaya musim hujan.

Lama waktu pertumbuhan miselium benih $\mathrm{F}_{0}$ pada media PDA dari ke 6 varietas jamur tiram putih yang dibudidayakan pada musim hujan (2,50 sampai 3,00 hari) lebih singkat dibandingkan dengan pada waktu budidaya di musim kemarau (3,00 sampai 4,75 hari). Hal ini mungkin karena nilai berbagai faktor cuaca di musim hujan (terutama suhu dan RH) optimal untuk mendukung pertumbuhan dan perkembangan miselium benih $\mathrm{F}_{0}$ pada media PDA dibandingkan pada budidaya musim kemarau.

\section{Pertumbuhan Vegetatif Miselium Pada Media Biji-Bijian}

Secara independen, waktu awal tumbuh miselium benih $\mathrm{F}_{1}$ pada media bijibijian dari enam varietas jamur tiram putih yang diteliti, sama (3,50 sampai 4,25 hsi). Demikian pula waktu budidaya berbeda menghasilkan waktu awal tumbuh miselium benih $F_{1}$ pada media biji-bijian yang sama (3,75 sampai 3,92 hsi). Kemungkinan berbagai sifat genetik dari berbagai varietas berbeda dan nilai faktor cuaca dari waktu tanam berbeda tidak dominan berpengaruh terhadap waktu awal tumbuh miselium benih $\mathrm{F}_{1}$ pada media biji-bijian (Tabel 3).

Tabel 3. Waktu awal tumbuh miselium benih $F_{1}$ jamur Tiram Putih pada media biji-bijian

\begin{tabular}{lc}
\hline Perlakuan & $\begin{array}{c}\text { Waktu awal tumbuh } \\
\text { miselium }\end{array}$ \\
\hline \multicolumn{1}{c}{ Varietas } & $\ldots$ hsi... \\
No. 1 & $3,50 \mathrm{a}$ \\
No. 30 & $4,00 \mathrm{a}$ \\
No. 37 & $4,25 \mathrm{a}$ \\
No. 38 & $3,50 \mathrm{a}$ \\
No. 46 & $4,00 \mathrm{a}$ \\
No. 85 (kontrol) & $3,75 \mathrm{a}$ \\
$\quad$ Musim & 3,92 a \\
Kemarau & 3,75 a \\
Hujan & $\mathrm{V}^{\mathrm{n}} ; \mathrm{M}^{\mathrm{n}} ; \mathrm{VM}^{\mathrm{tn}}$ \\
Hasil analisis sidik & $\mathrm{KK}_{1}: 12,40 \%$ \\
ragam &
\end{tabular}


Tabel 4. Interaksi antara varietas dengan musim terhadap waktu akhir tumbuh miselium benih dan lama waktu pertumbuhan miselium benih $\mathrm{F}_{1}$ jamur tiram putih memenuhi media biji-bijian

\begin{tabular}{|c|c|c|c|c|}
\hline \multirow{3}{*}{$\begin{array}{l}\text { Perlakuan } \\
\text { Varietas }\end{array}$} & \multicolumn{2}{|c|}{$\begin{array}{l}\text { Waktu akhir tumbuh miselium } \\
\text { benih } F_{1} \text { pada media biji-bijian }\end{array}$} & \multicolumn{2}{|c|}{$\begin{array}{l}\text { Lama waktu miselium benih } \mathrm{F}_{1} \text { jamur } \\
\text { Tiram Putih memenuhi media biji-bijian }\end{array}$} \\
\hline & \multicolumn{2}{|c|}{ Musim } & \multicolumn{2}{|c|}{ Musim } \\
\hline & Kemarau & Hujan & Kemarau & Hujan \\
\hline & .hsi.. & ..hsi.. & ..hsi.. & ..hsi.. \\
\hline No. 1 & $\begin{array}{c}17,75 \mathrm{c} \\
\mathrm{B}\end{array}$ & $\begin{array}{c}24,75 \mathrm{~b} \\
\mathrm{~A}\end{array}$ & $\begin{array}{c}14,50 \mathrm{c} \\
\mathrm{B}\end{array}$ & $\begin{array}{c}21,00 \mathrm{~b} \\
\mathrm{~A}\end{array}$ \\
\hline No. 30 & $\begin{array}{l}20,75 \text { bc } \\
\text { A }\end{array}$ & $\begin{array}{l}26,00 \mathrm{~b} \\
\mathrm{~A}\end{array}$ & $\begin{array}{l}16,75 \mathrm{bc} \\
\mathrm{B}\end{array}$ & $\begin{array}{c}22,00 \\
\mathrm{~A}\end{array}$ \\
\hline No. 37 & $\begin{array}{c}28,50 \text { a } \\
\text { A }\end{array}$ & $\begin{array}{c}25,75 \mathrm{~b} \\
\mathrm{~A}\end{array}$ & $\begin{array}{c}23,75 \text { a } \\
\text { A }\end{array}$ & $\begin{array}{c}22,00 \\
\mathrm{~A}\end{array}$ \\
\hline No. 38 & $\begin{array}{c}22,50 \mathrm{~b} \\
\mathrm{~A}\end{array}$ & $\begin{array}{c}26,75 \mathrm{~b} \\
\mathrm{~A}\end{array}$ & $\begin{array}{c}19,00 \mathrm{~b} \\
\mathrm{~A}\end{array}$ & $\begin{array}{c}23,25 \text { ab } \\
\mathrm{A}\end{array}$ \\
\hline No. 46 & $\begin{array}{c}22,50 \mathrm{~b} \\
\mathrm{~A}\end{array}$ & $\begin{array}{c}29,25 \text { a } \\
\text { A }\end{array}$ & $\begin{array}{l}18,25 \mathrm{bc} \\
\mathrm{B}\end{array}$ & $\begin{array}{c}25,75 \text { ab } \\
\text { A }\end{array}$ \\
\hline No. 85 (kontrol) & $\begin{array}{c}19,25 \mathrm{~b} \\
\mathrm{C}\end{array}$ & $\begin{array}{c}24,75 \text { b } \\
\text { A }\end{array}$ & $\begin{array}{l}16,75 \mathrm{bc} \\
\mathrm{B}\end{array}$ & $\begin{array}{c}21,00 \text { a } \\
\mathrm{A}\end{array}$ \\
\hline $\begin{array}{l}\text { Hasil Analisis Sidik } \\
\text { Ragam }\end{array}$ & $\begin{array}{l}\mathrm{V}^{\mathrm{n}} ; \\
\mathrm{KK}\end{array}$ & & & \\
\hline
\end{tabular}

Keterangan: Pada kolom yang diikuti huruf yang sama tidak berbeda pada uji Duncan 5\%

Tabel 5. Waktu awal tumbuh, waktu akhir tumbuh, dan lama waktu pertumbuhan miselium benih $\mathrm{F}_{2}$ Jamur Tiram Putih Pada Media Produksi/Substrat

\begin{tabular}{|c|c|c|c|}
\hline Perlakuan & $\begin{array}{l}\text { Waktu awal tumbuh } \\
\text { miselium benih } \mathrm{F}_{2}\end{array}$ & $\begin{array}{l}\text { Waktu akhir tumbuh } \\
\text { miselium benih } F_{2}\end{array}$ & $\begin{array}{l}\text { Lama waktu pertumbuhan } \\
\text { miselium benih } F_{2}\end{array}$ \\
\hline Varietas & ... hsi... & ...hsi... & ...hsi... \\
\hline No. 1 & 12,38 a & $35,63 \mathrm{~b}$ & $23,13 \mathrm{~b}$ \\
\hline No. 30 & 12,38 a & $35,88 \mathrm{~b}$ & $23,38 \mathrm{~b}$ \\
\hline No. 37 & $12,50 \mathrm{a}$ & $34,50 \mathrm{~b}$ & $21,88 \mathrm{~b}$ \\
\hline No. 38 & $12,25 \mathrm{a}$ & $36,50 \mathrm{~b}$ & $24,50 \mathrm{~b}$ \\
\hline No. 46 & $11,63 \mathrm{~b}$ & 41,38 a & 29,75 a \\
\hline $\begin{array}{l}\text { No. } 85 \text { (kontrol) } \\
\text { Musim }\end{array}$ & $11,50 \mathrm{~b}$ & $36,63 \mathrm{~b}$ & $25,13 \mathrm{~b}$ \\
\hline Kemarau & 20,71 a & 46,38 a & 25,63 a \\
\hline Hujan & $30,56 \mathrm{~b}$ & $27,93 \mathrm{~b}$ & 23,63 a \\
\hline $\begin{array}{l}\text { Hasil analisis } \\
\text { sidik ragam }\end{array}$ & $\begin{array}{l}\mathrm{V}^{\mathrm{n}} ; \mathrm{M}^{\mathrm{n}} ; \mathrm{VM}^{\mathrm{tn}} \\
\mathrm{KK}=8,46 \%\end{array}$ & $\begin{array}{l}\mathrm{V}^{\mathrm{n}} ; \mathrm{M}^{\mathrm{n}} ; \mathrm{VM}^{\mathrm{tn}} \\
\mathrm{KK}=1,55 \%\end{array}$ & $\begin{array}{l}\mathrm{V}^{\mathrm{n}} ; \mathrm{M}^{\mathrm{n}} ; \mathrm{VM}^{\mathrm{tn}} \\
\mathrm{KK}=3,30 \%\end{array}$ \\
\hline
\end{tabular}

Keterangan: Pada kolom yang diikuti huruf yang sama tidak berbeda pada uji Duncan 5\%

Pada Tabel 4 ditunjukkan adanya interaksi antara varietas dan waktu budidaya terhadap waktu akhir tumbuh dan lama waktu pertumbuhan miselium benih $\mathrm{F}_{1}$ pada media biji-bijian. Varietas No. 1 yang dibudidayakan musim kemarau, memberikan waktu akhir tumbuh miselium benih $F_{1}$ pada media biji-bijian yang terlama $(29,25$ hsi).
Varietas No. 1, 30, 46 dan 85 (lokal bogor) yang dibudidayakan pada musim kemarau, memberikan lama waktu pertumbuhan miselium benih $\mathrm{F}_{1}$ pada media biji-bijian yang tersingkat (14,50-8,25 hari) dibandingkan dengan budidaya pada musim hujan (21,00 sampai 25,75 hari). Hal ini mungkin karena berbagai nilai faktor cuaca (terutama suhu dan $\mathrm{rH}$ udara) di musim 
kemarau tidak optimal untuk mendukung pertumbuhan dan perkembangan miselium benih $F_{1}$ pada media biji-bijian.

\section{Pertumbuhan Vegetatif Miselium Benih F2 Jamur Tiram Putih Pada Media Produksi}

Waktu awal tumbuh miselium benih $F_{2}$ varietas No. 1, 30, 37, dan 38 pada media produksi lebih cepat dibandingkan dengan varietas No. 46 dan No. 85 (lokal bogor) (Tabel 5). Dalam hal ini sifat genetik berbeda yang terkandung dalam varietas berbeda, menentukan pengawalan tumbuh miselium benih $\mathrm{F}_{2}$ pada media produksi. Waktu budidaya ke enam varietas pada musim kemarau mempercepat waktu awal tumbuh miselium benih $\mathrm{F}_{2}$ pada media produksi. Mungkin berbagai nilai faktir cuaca di musim kemarau mempengaruhi terjadi percepatan waktu awal tumbuh tersebut.

Varietas No. 46 menghasilkan waktu awal tumbuh miselium benih $\mathrm{F}_{2}$ pada media produksi yang paling lambat (41,38 hsi), sedangkan ke 5 varietas lainnya sama. Hal ini berdampak pada lama waktu pertumbuhan miselium benih $\mathrm{F}_{2}$ tumbuh memenuhi media produksi yang terlama (29,75 hari) dibandingkan dengan kelima varietas tersebut. Secara independen, lama waktu pertumbuhan miselium benih $\mathrm{F}_{2}$ memnuhi media produksi yang berasal dari waktu budidaya musim kemarau sama dengan pada musim hujan.

\section{Waktu panen, Serta Lama Waktu Jamur Tiram Putih Berproduksi}

Waktu awal panen ke 6 varietas jamur tiram putih tidak berbeda (antara 52,63 sampai 57,63 hsi). Mungkin berbagai sifat genetik berbeda tidak mempengaruhi pengawalan panen ke 6 varietas jamur tiram putih yang diuji. Namun, secara independen, waktu budidaya ke 6 varietas jamur tiram putih nyata berpengaruh terhadap waktu awal panen jamur. Budidaya pada musim hujan mennghasilkan waktu awal panen jamur tiram putih yang nyata lebih cepat
$(49,13$ hsi) dibandingkan dengan waktu budidaya musim kemarau (63,29 hsi). Hal ini terjadi, mungkin diakibatkan berbagai nilai faktor lingkungan cuaca (terutama nilai suhu dan $\mathrm{rH}$ ) di musim kemarau lebih ooptimal mendukung pertumbuhan dan perkembangan jamur tiram putih dibanding musim hujan, jamur tiram putih tumbuh dan berkembang lebih lama sehingga waktu awal panen menjadi lebih lambat.

Tabel 6. Waktu awal panen enam varietas jamur Tiram Putih dibudidayakan pada musim kemarau dan musim hujan

\begin{tabular}{lc}
\hline \multicolumn{1}{c}{ Perlakuan } & $\begin{array}{c}\text { Waktu Awal Panen } \\
\text { Jamur Tiram Putih }\end{array}$ \\
\hline \multicolumn{1}{c}{ Varietas } & .hsi.. \\
No. 1 & $57,13 \mathrm{a}$ \\
No. 30 & $55,13 \mathrm{a}$ \\
No. 37 & $52,63 \mathrm{a}$ \\
No. 38 & $57,38 \mathrm{a}$ \\
No. 46 & $57,63 \mathrm{a}$ \\
No. 85 (kontrol) & $57,63 \mathrm{a}$ \\
$\quad$ Musim & \\
Kemarau & $63,29 \mathrm{a}$ \\
Hujan & $49,13 \mathrm{~b}$ \\
\hline Hasil analisis sidik & $\mathrm{V}^{\mathrm{tn}} ; \mathrm{M}^{\mathrm{n}} ; \mathrm{VM}^{\mathrm{tn}}$ \\
ragam & $\mathrm{KK}^{2}=7,95 \%$ \\
\hline Ke
\end{tabular}

Keterangan: Rerata yang diikuti huruf yang sama tidak berbeda pada uji Duncan 5\%

Tabel 7. Secara umum, waktu akhir panen ke 6 varietas jamur tiram putih yang dibudidayakan pada musim kemarau nyata lebih lama (135,75 sampai 139,75 hsi) dibandingkan dengan pada budidaya musim hujan (77,00 sampai 107,75 hsi). Mungkin berbagai nilai faktor cuaca di musim kemarau lebih optimal dibanding pada musim hujan bekerja sama mempengaruhi waktu akhir panen jamur tiram putih di Bogor. Budidaya ke 6 varietas jamur tiram putih pada musim kemarau menghasilkan lama waktu jamur tiram putih berproduksi yang nyata lebih panjang dibandingkan dengan pada budidaya musim hujan di Bogor. 
Tabel 7. Interaksi antara varietas dan musim terhadap waktu akhir panen dan lama waktu berproduksi

\begin{tabular}{|c|c|c|c|c|}
\hline \multirow[t]{2}{*}{$\begin{array}{l}\text { Perlakuan } \\
\text { Varietas }\end{array}$} & \multicolumn{2}{|c|}{$\begin{array}{c}\text { Waktu Akhir Panen } \\
\text { Musim }\end{array}$} & \multicolumn{2}{|c|}{$\begin{array}{c}\text { Lama Waktu Berproduksi } \\
\text { Musim }\end{array}$} \\
\hline & $\begin{array}{l}\text { Kemarau } \\
\text {..hsi.. }\end{array}$ & $\begin{array}{l}\text { Hujan } \\
\text {..hsi.. }\end{array}$ & $\begin{array}{l}\text { Kemarau } \\
\text {..hari.. }\end{array}$ & $\begin{array}{l}\text { Hujan } \\
\text {..hari.. }\end{array}$ \\
\hline No. 1 & $\begin{array}{c}139,75 \text { a } \\
\text { A }\end{array}$ & $\begin{array}{c}107,75 \text { a } \\
\text { B }\end{array}$ & $\begin{array}{c}75,75 \mathrm{ab} \\
\mathrm{A}\end{array}$ & $\begin{array}{c}57,50 \text { bc } \\
\text { B }\end{array}$ \\
\hline No. 30 & $\begin{array}{c}139,50 \mathrm{a} \\
\mathrm{A}\end{array}$ & $\begin{array}{c}107,50 \mathrm{a} \\
\mathrm{B}\end{array}$ & $\begin{array}{c}77,25 \text { a } \\
\text { A }\end{array}$ & $\begin{array}{c}60,50 \mathrm{ab} \\
\mathrm{B}\end{array}$ \\
\hline No. 37 & $\begin{array}{c}138,50 \mathrm{a} \\
\mathrm{A}\end{array}$ & $\begin{array}{c}107,75 \mathrm{a} \\
\mathrm{B}\end{array}$ & $\begin{array}{c}77,75 \text { a } \\
\text { A }\end{array}$ & $\begin{array}{c}63,25 \text { a } \\
\text { B }\end{array}$ \\
\hline No. 38 & $\begin{array}{c}135,75 \mathrm{~b} \\
\mathrm{~A}\end{array}$ & $\begin{array}{c}77,00 \mathrm{c} \\
\mathrm{B}\end{array}$ & $\begin{array}{c}74,75 \mathrm{ab} \\
\mathrm{A}\end{array}$ & $\begin{array}{c}25,00 \text { e } \\
\text { B }\end{array}$ \\
\hline No. 46 & $\begin{array}{c}138,25 \mathrm{a} \\
\mathrm{A}\end{array}$ & $\begin{array}{c}103,25 \mathrm{~b} \\
\mathrm{~B}\end{array}$ & $\begin{array}{c}72,25 \mathrm{~b} \\
\mathrm{~A}\end{array}$ & $\begin{array}{c}54,00 \mathrm{~d} \\
\mathrm{~B}\end{array}$ \\
\hline No. 85 (kontrol) & $\begin{array}{c}138,25 \text { a } \\
\text { A }\end{array}$ & $\begin{array}{c}107,50 \mathrm{a} \\
\mathrm{B}\end{array}$ & $\begin{array}{c}74,25 \mathrm{ab} \\
\mathrm{A}\end{array}$ & $\begin{array}{c}56,75 \mathrm{~cd} \\
\text { B }\end{array}$ \\
\hline $\begin{array}{l}\text { Hasil Analisis } \\
\text { Sidik Ragam }\end{array}$ & $\begin{array}{l}\mathrm{V}^{\mathrm{n}} \\
\mathrm{KK}\end{array}$ & & $\begin{array}{l}\mathrm{V}^{\mathrm{n}} \\
\mathrm{KK}\end{array}$ & \\
\hline
\end{tabular}

Keterangan: Pada kolom yang diikuti huruf yang sama tidak berbeda pada uji Duncan 5\%

Tabel 8. Komponen hasil panen enam varietas jamur Tiram Putih dibudidayakan pada musim kemarau dan musim hujan

\begin{tabular}{|c|c|c|c|c|c|}
\hline Perlakuan & $\begin{array}{l}\text { Diameter } \\
\text { Tudung }\end{array}$ & $\begin{array}{l}\text { Tebal } \\
\text { Tudung }\end{array}$ & $\begin{array}{c}\text { Diameter } \\
\text { Tangkai } \\
\text { Tudung }\end{array}$ & $\begin{array}{l}\text { Panjang } \\
\text { Tangkai } \\
\text { Tudung }\end{array}$ & $\begin{array}{c}\text { Jumlah } \\
\text { Tudung Per } \\
\text { Baglog }\end{array}$ \\
\hline Varietas & ..cm.. & ..cm.. & ..cm.. & ..cm.. & ..cm.. \\
\hline No. 1 & 8,15 a & $0,75 \mathrm{a}$ & $0,97 \mathrm{ab}$ & $2,90 \mathrm{a}$ & $11,85 \mathrm{a}$ \\
\hline No. 30 & 7,75 a & 0,76 a & $0,97 \mathrm{ab}$ & $2,62 \mathrm{a}$ & 13,28 a \\
\hline No. 37 & 8,38 a & $0,81 \mathrm{a}$ & $1,07 \mathrm{a}$ & $2,85 \mathrm{a}$ & $14,47 \mathrm{a}$ \\
\hline No. 38 & $7,61 \mathrm{a}$ & $0,65 \mathrm{a}$ & $0,88 \mathrm{ab}$ & $2,86 \mathrm{a}$ & $9,26 \quad \mathrm{a}$ \\
\hline No. 46 & 7,26 a & 0,72 a & $0,78 \mathrm{~b}$ & $2,91 \mathrm{a}$ & $19,65 \mathrm{a}$ \\
\hline $\begin{array}{c}\text { No. } 85 \text { (kontrol) } \\
\text { Musim }\end{array}$ & 8,22 a & 0,75 a & $0,88 \mathrm{ab}$ & 3,07 a & 14,23 a \\
\hline Kemarau & 8,39 a & $0,85 \mathrm{a}$ & 0,98 a & $3,14 \mathrm{a}$ & 16,73 a \\
\hline Hujan & $7,40 \mathrm{~b}$ & $0,63 \mathrm{~b}$ & $0,87 \mathrm{a}$ & $2,59 \mathrm{~b}$ & $10,75 \mathrm{~b}$ \\
\hline $\begin{array}{l}\text { Hasil analisis } \\
\text { sidik ragam }\end{array}$ & $\begin{array}{l}\mathrm{V}^{\mathrm{tn}} ; \mathrm{M}^{\mathrm{n}} ; \mathrm{VM}^{\mathrm{tn}} \\
\mathrm{KK}=9,93 \%\end{array}$ & $\begin{array}{l}\mathrm{V}^{\mathrm{tn}} ; \mathrm{M}^{\mathrm{n}} ; \mathrm{VM}^{\mathrm{tn}} \\
\mathrm{KK}=7,17 \%\end{array}$ & $\begin{array}{l}\mathrm{V}^{\mathrm{tn}} ; \mathrm{M}^{\mathrm{n}} ; \mathrm{VM}^{\mathrm{tn}} \\
\mathrm{KK}=24,22 \%\end{array}$ & $\begin{array}{l}\mathrm{V}^{\mathrm{tn}} ; \mathrm{M}^{\mathrm{n}} ; \mathrm{VM}^{\mathrm{tn}} \\
\mathrm{KK}=8,27 \%\end{array}$ & $\begin{array}{l}\mathrm{V}^{\mathrm{tn}} ; \mathrm{M}^{\mathrm{n}} ; \mathrm{VM}^{\mathrm{tn}} \\
\mathrm{KK}=24,32 \%\end{array}$ \\
\hline
\end{tabular}

Keterangan: Pada kolom yang diikuti huruf yang sama tidak berbeda pada uji Duncan 5\%

\section{Komponen Hasil Panen Jamur Tiram Putih}

Tabel 8. Secara independen, ke 6 varietas jamur tiram putih yang diuji, tidak berpengaruh terhadap komponen hasil jamur (diameter dan tebal tudung, panjang tangkai tudung, dan jumlah tudung jamur per baglog), namun berpengaruh nyata terhadap diameter tangkai tudung jamur tiram putih. Diameter tangkai tudung jamur tiram putih yang terbesar dihasilkan oleh varietas- 
varietas No. $37(1,01 \mathrm{~cm})$ dan yang terkecil dari varietas No. $46(0,78 \mathrm{~cm})$.

Secara independen, waktu budidaya pada musim kemarau, nyata meningkatkan diameter dan tebal tudung, panjang tangkai tudung, dan jumlah tudung jamur tiram putih per baglog, namun tidak berpengaruh terhadap ukuran diameter tangkai tudung. Kemungkinan, berbagai nilai faktor cuaca di musim kemarau optimal untuk meningkatkan ke 4 peubah komponen hasil ke 6 varietas jamur tiram putih yang diuji, kecuali terhadap diameter tangkai tudung.

\section{Hasil Panen Jamur}

Secara independen, varietas tidak berpengaruh terhadap produksi bobot segar total jamur tiram putih yang diuji di Bogor sepanjang tahun. Hasil bobot segar total ke 6 varietas jamur tiram putih yang diuji di Bogor, sama $(54,78$ sampai 91,08 ton per $1000 \mathrm{~m}^{2}$ luas kumbung). Namunn hasil produksi bobot total jamur tiram putih yang tertinggi $\left(91,08\right.$ ton per $\left.1000 \mathrm{~m}^{2} \mathrm{LK}\right)$ berasal dari varietas No. 1, dan yang terendah dari varietas No. 38 (54,78 ton per $\left.1000 \mathrm{~m}^{2} \mathrm{LK}\right)$ (Tabel 9). Hasil jamur yang tinggi ini didukung oleh pertumbuhan dan perkembangan miselium benih jamur tiram putih yang optimal pada berbagai media tumbuh yang mendorong terhadap tingginya nilai berbagai peubah komponen hasil di muka, sehingga menunjang produksi bobot segar total jamur tiram putih pada akhirnya.

Secara independen, waktu budidaya ke 6 varietas jamur tiram putih pada musim kemarau (91,32 ton per $\left.1000 \mathrm{~m}^{2} \mathrm{LK}\right)$ nyata lebih tinggi daripada budidaya di musim hujan (61,76 ton per $\left.1000 \mathrm{~m}^{2} \mathrm{LK}\right)$. Ini terjadi mungkin karena berbagai nilai faktor cuaca di musim kemarau optimal mendukung pertumbuhan miselium benih pada berbagai media tumbuh, pertumbuhan dan perkembangan jamur tiram putih, hasil dan komponen hasil bobot total jamur pada akhirnya.

Tabel 9. Produksi bobot segar total jamur Tiram Putih dibudidayakan musim kemarau dan musim hujan

\begin{tabular}{lc}
\hline Perlakuan & $\begin{array}{c}\text { Produksi Bobot Segar } \\
\text { Total Jamur Tiram Putih } \\
\text { (ton per 1000 } \mathrm{m}^{2} \text { luas } \\
\text { kumbung) }\end{array}$ \\
\hline Varietas & $91,08 \mathrm{a}$ \\
No. 30 & $74,36 \mathrm{a}$ \\
No. 37 & $78,70 \mathrm{a}$ \\
No. 38 & $54,78 \mathrm{a}$ \\
No. 46 & $78,91 \mathrm{a}$ \\
No. 85 (kontrol) & $81,40 \mathrm{a}$ \\
$\quad$ Musim & $91,32 \mathrm{a}$ \\
Kemarau & $61,76 \mathrm{~b}$ \\
Hujan & $\mathrm{V}^{\mathrm{n}} ; \mathrm{M}^{\mathrm{n}} ; \mathrm{VM}^{\mathrm{tn}}$ \\
\hline Hasil analisis & $\mathrm{KK}^{2}=10,28 \%$ \\
sidik ragam &
\end{tabular}

Keterangan: Rerata yang diikuti huruf yang sama tidak berbeda pada uji Duncan 5\%

\section{Kualitas Jamur Tiram Putih}

Secara independen, ke 6 varietas jamur tiram putih yang dibudidayakan sepanjang tahun di Bogor - Jawa Barat, tidak berpengaruh terhadap kadar air jamur, namun berpengaruh nyata terhadap rasa dan ketahanan simpan jamur tiram putih yang disimpan di ruang bersuhu kamar / ambient temperature (Tabel 10). Rasa ke enam varietas jamurtiram putih yang diuji, sama lezatnya yaitu dengan nilai ranking tes rasa antara 1,99 $-2,52$. Nilai ranking tes rasa $<3$ termasuk enak rasanya. 
Tabel 10. Kualitas enam varietas jamur Tiram Putih dibudidayakan pada musim kemarau dan musim hujan

\begin{tabular}{|c|c|c|c|}
\hline Perlakuan & $\begin{array}{l}\text { Rasa Jamur Tiram } \\
\text { Putih * } \\
\text { Nilai ranking: } 1-4\end{array}$ & $\begin{array}{c}\text { Kadar Air Jamur } \\
\text { Tiram Putih } \\
\%\end{array}$ & $\begin{array}{c}\text { Ketahanan Simpan } \\
\text { Jamur Tiram Putih } \\
\text { Pada Suhu Kamar } \\
\text { Hari }\end{array}$ \\
\hline No. 1 & $1,99 \mathrm{c}$ & 92,62 a & $2,63 \mathrm{a}$ \\
\hline No. 30 & $2,07 \mathrm{bc}$ & 93,75 a & $1,75 \mathrm{ab}$ \\
\hline No. 37 & $2,52 \mathrm{a}$ & 93,17 a & $1,69 \mathrm{ab}$ \\
\hline No. 38 & $2,39 \mathrm{ab}$ & 92,67 a & $2,00 \mathrm{a}$ \\
\hline No. 46 & $2,20 \mathrm{abc}$ & 92,63 a & $1,88 \mathrm{ab}$ \\
\hline No. 85 (kontrol) & $2,20 \mathrm{abc}$ & 93,12 a & $1,56 \mathrm{~b}$ \\
\hline \multicolumn{4}{|l|}{ Musim } \\
\hline Kemarau & $2,35 \mathrm{a}$ & $92,75 \mathrm{a}$ & 1,79 a \\
\hline Hujan & $2,10 \mathrm{a}$ & 91,19 a & $1,83 \mathrm{a}$ \\
\hline Hasil analisis sidik & $\mathrm{V}^{\mathrm{n}} ; \mathrm{M}^{\mathrm{tn}} ; \mathrm{VM}^{\mathrm{tn}}$ & $\mathrm{V}^{\mathrm{n}} ; \mathrm{M}^{\mathrm{tn}} ; \mathrm{VM}^{\mathrm{tn}}$ & $\mathrm{V}^{\mathrm{n}} ; \mathrm{M}^{\mathrm{t}} ; \mathrm{VM}^{\mathrm{tn}}$ \\
\hline ragam & $\mathrm{KK}=18,16 \%$ & $\mathrm{KK}=8,92 \%$ & $\mathrm{KK}=10,28 \%$ \\
\hline
\end{tabular}

Varietas No.1 memberikan nilai ketahanan simpan terlama (2,63 hari) pada ruang bersuhu kamar di Bogor. Varietas No. 85 (lokal Bogor) menghasilkan ketahanan simpan yang tersingkat (1,56 hari), padahal diketahui bahwa varietas No. 85 ini merupakan varietas lokal/ kontrol yang telah lama beradaptasi di Bogorserta biasa digunakan oleh petani setempat untuk usaha taninya selama ini rupannya varietas No. 85 ini berproduksi tinggi dan lezat rasanya, namun ketahan simpannya termasuk rendah/ singkat. Mungkin hal ini akan mengubah petani jamur tiram putih di Bogor di masa depan untuk mau mengganti pemakain varietas No. 85/ lokal dengan varietas lainnya yang berproduksi dan berkualitas tinggi yang telah diuji sepanjang tahun di Bogor.

\section{KESIMPULAN}

(1) Produksi bobot segar total ke 6 varietas jamur tiram putih yang diuji tidak berbeda nyata dengan hasil antara 54,78 sampai 91,08 ton per $1000 \mathrm{~m}^{2}$ luas kumbung. Varietas No.1, memberikan hasil jamur tertinggi (91,08 ton), disusul oleh varietas No. 85/lokal Bogor $(81,40$ $\left.\mathrm{t} / 1000 \mathrm{~m}^{2} \mathrm{LK}\right)$. Ke 6 varietas jamur tiram putih tersebut hasilnya $>50 \mathrm{t} / 1000 \mathrm{~m}^{2}$ LK, yang dapat direkomendasikan sebagai varietas unggul baru jamur tiram putih.

(2) Budidaya jamur tiram putih di Bogor pada musim kemaru menghasilkan produksi bobot segar total jamur nyata lebih tinggi dari produksi jamur dibudidayakan pada musim hujan $(91,32$ Vs. 61,76 ton per $1000 \mathrm{~m}^{2}$ luas kumbung).

(3) Kualitas rasa dan ketahanan simpan dipengaruhi oleh varietas jamur Tiram Putih. Budidaya pada musim kemarau menghasilkan kualitas jamur tiram putih yang sama tingginya dibandingkan dengan kualitas jamur yang dibudidayakan pada musim hujan di Bogor yaitu rasa enak/ nilai ranking $<3$, ketahanan simpan pada suhu kamar $>2$ hari, dan kadar air $>90 \%$.

\section{DAFTAR PUSTAKA}

Chang, S. 2008. Overview of Mushroom Cultivation and Utilization as Functional Foods. In P.C.K. Cheung (Ed). Mushrooms as Functional Foods. John Wiley \& Sons. New Jersey. Pp. 1-33

Djuariah, D., dan Sumiati, E. 2005a. Koleksi, Pemurnian Dan Konservasi Jamur Edible Komersial Asal Berbagai Tempat di Jawa- 
Bali dan Introduksi Dari Luar Negeri. Laporan Penelitian APBN TA. 2005. Balitsa. 20 p.

Djuariah, D., dan Sumiati, E. 2005b. Uji Daya Hasil Dan Kualitas Hasil Lima Belas Strain Jamur Tiram Di Dataran Tinggi Lembang. Laporan Penelitian APBN TA. 2006. BALITSA. 9 p.

Djuariah, D., dan Sumiati, E. 2006. Perbandingan Daya Hasil Dan Karakteristik Beberapa Species Jamur Tiram Pleurotus Spp. Laporan Penelitian APBN TA. 2005. BALITSA. 7 p.

Djuariah, D., dan E. Sumiati. 2007. Penampilan Fenotipik Delapan Strain Jamur Tiram Putih Pleurotus ostreatus Di Dataran Tinggi Lembang. Prosiding Seminar Peran Bioteknologi Dalam Rehabilitasi Lahan Kritis Di Tatar Sunda. Bandung 4 September 2007. Jurusan ilmu tanah dan sumber daya lahan, Fakultas Pertanian UNPAD, AMI Jabar, dan HITI Jabar. Pp. 128-134.

Djuariah, D., dan Sumiati, E. 2008a. Uji Daya Hasil Dan Kualitas 21 Strain Jamur Tiram Di Lembang. Laporan Penelitian APBN TA. 2006. BALITSA. 12 p.

Djuariah, D., dan Sumiati., E. 2008b. Perbandingan Daya Hasil Dan Karakteristik Dua Puluh Tujuh Strain Jamur Tiram Putih (Pleurotus ostreatus). Prosiding Seminar Nasional Pekan
Kentang 2008. Vol. 2: 557-566. Lembang 20-21 Agustus 2008. Departemen Pertanian. Badan Penelitian Dan Pengembangan Pertanian. Pusat Penelitian Dan Pengembangan Hortikultura.

Oei, P., 2003. Mushroom Cultivation $3^{\text {rd }}$ Edition. Appropriate Technology for Mushroom Growers. The Netherlands: Backhuys.

Pantastico, E.B., 1989. Fisiologi Pasca Panen. In Penanganan dan Pemanfaatan Buahbuahan dan Sayuran Tropika dan Subtropika. Yogyakarta: Gajah Mada University Press. p.906.

Pasaribu, Permana \& Alda, 2002. Aneka Jamur Unggulan Yang Menembus Pasar. Jakarta: Gramedia Widiasarana Indonesia.

Stamets, P., 2000. Growing Gourmet and Medicinal Mushrooms. Herbal Gram 54: $28-33$.

Sumiati, E. \& Djuariah, D., 2009. Masalah Budidaya Jamur Edibel di Pulau Jawa dan Bali. Jurnal Agrikultura, 20(2): 122 - 129.

Valverde, M.E., Hernández-Pérez, T. and Paredes-López, O. 2015. Edible Mushrooms: Improving Human Health and Promoting Quality Life. International Journal of Microbiology Volume 2015. Article ID 376387. http://dx.doi.org/10.1155/2015/376387. 